10 years ESJ

Special edition

\title{
The Impact of Portuguese Economic and Financial Assistance Program on the Employability of the Azorean Nurse after the Financial Crisis of 2009-2010
}

\author{
Luis Carlos do Rego Furtado
}

Hospital do Divino Espírito Santo de Ponta Delgada EPER, Portugal

\section{Doi:10.19044/esj.2022.v18n5p49}

Submitted: 09 August 2021

Accepted: 20 September 2021

Published: 21 February 2022
Copyright 2022 Author(s)

Under Creative Commons BY-NC-ND

4.0 OPEN ACCESS

Cite As:

Rego Furtado L.C. (2022). The Impact of Portuguese Economic and Financial Assistance Program on the Employability of the Azorean Nurse after the Financial Crisis of 2009-2010. European Scientific Journal, ESJ, 18 (5), 49. https://doi.org/10.19044/esj.2022.v18n5p49

\section{Abstract}

The economic crisis that followed the financial crisis that began in the United States of America in 2008 quickly spread to the whole world, leaving structural problems in several countries unveiled, particularly in those that, due to successive deficits and high external indebtedness, were in a more fragile situation. In the Portuguese case, external assistance was needed, made available in exchange for structural reforms and the abrupt, and severe reduction in public expenditure. The applied austerity had repercussions throughout society, but the public sector felt the weight of the used measures concretely, with health services being no exception. The shock waves caused by public expenditure containment policies were particularly felt in the Azores, an ultra peripheral region marked by geographical discontinuity. These are significant asymmetries at various levels from island to island and across several sectors. The public sector is the primary employer. This paper focuses on understanding if the Portuguese Economic and Financial Assistance Program, implemented between 2011 and 2014, affected the employability and dynamics of the labour market of new graduate nurses in the Autonomous Region of the Azores. This quantitative study used descriptive, inferential, and correlation statistics to establish relations with a statistical value between the sample's employability dimensions and the Portuguese Economic and Financial Assistance Program. From the analysis carried out, the study revealed that the restrictions imposed due to the external 
assistance program led to an increase in precariousness among new graduate nurses and, among other conclusions, a strong contraction in the capacity of hiring nurses by the public health services. As a limitation to the study, there is the need to emphasise that data on unemployment reflected the reality when the questionnaire was applied (May 2019), and the fact that the study did not explore the reasons underlying the unemployment rate found among the participants (although residual).

Keywords: Unemployment, nursing, economic crisis, youth unemployment, employment precariousness

\section{Introduction}

Economic recessions are a relatively recurrent phenomenon. Following the 2008 financial crisis in the United States of America, world economies experienced a period of economic instability, which impacted health systems and health outcomes (Leão et al., 2018). There is now sufficient evidence to support that economic recessions affect the health and the healthcare populations (Karanikolos et al., 2013). Nonetheless, this effect is not always straightforward and seems to be dependent on the policy responses to crisis (Kentikelenis, 2017). Between 2009 and 2014, Portugal was subject to one of the most severe debt crises in its history, which led, in May 2011, to the Portuguese Economic and Financial Assistance Program. Thus, this is in agreement between the European Commission, the European Central Bank and the International Monetary Fund (usually referred in the literature as "Troika") - in exchange to a 78 billion euros loan referred to as financial rescue package or bailout programme. The program aimed to restore the international financial markets' confidence, and promote competitiveness and sustainable economic growth based on three pillars: fiscal consolidation, financial system stability, and the Portuguese structural transformation of the economy (Portugal Bank, 2015).

The adjustment implications of the program for public services in countries under external intervention were tremendous - being Portugal, Ireland, Greece, and Spain, which are possibly the worst affected. Thus, they experience very substantial reductions in public expenditure, which affected public service functioning and response capacity, and conditioned the hiring of human resources. This situation directly impacted the hiring to replace civil employees who left for retirement or suppress pre-existing needs, and aggravating longstanding structural deficits in essential services (Faramarzi et al., 2019).

As a result of the adopted measures, the consequent economic crisis had a devastating effect on living conditions across Europe (with a particular incidence in the countries mentioned above), mainly with a precipitous rise in 
unemployment (Al-Sawai'e \& Abdul, 2015; Liotti, 2020). This aggravated a situation that had been deteriorating from 2007 onwards, with a trend of rising unemployment throughout almost all Europe (Boeri \& Jimeno, 2016). Unemployment impacts the whole society because it represents a fiscal cost for the community, contributing in the long-term to public finance imbalances, and also worsening of the debt/Gross Domestic Product ratio. Furthermore, suppose it persists for a prolonged amount of time, unemployment produces a set of negative consequences among which are the loss of human capital, lower employability, lower levels of expected earnings in the future, and adverse effects on an individual's physical and psychological well-being (Benach et al., 2014; Arulampalam et al., 2000).

The austerity measures imposed on the country and its population, aiming at structural reforms in the public sector, did not leave out the Portuguese National Health Service (NHS), as happened in all intervened countries, which already suffered from considerably structural, financing, and organisational problems with severe cuts to health budgets (Kentikelenis \& Papanicolas, 2012; Simou \& Koutsogeorgou, 2014; Sawai'e \& Abdul, 2015).

Without limiting the magnitude of the cuts imposed on health budgets, and with the aggravation of the severity of the measures and cuts applied throughout the program, there was a very considerable negative impact on health care services belonging to the countries most affected by the economic and financial crisis. This considerably affected their ability to respond to people's health needs, and the motivation and work environment of health workers (Keegan et al., 2013; Thomas et al., 2013). In any case, human resources are considered as the most critical inputs into a health system whose performance is dependent on the morale and staff who provide and manage care, as well as on the number of health care professionals available to secure care within acceptable quality and safety parameters (Frenk, 2010).

\section{Background}

\section{The Azores Archipelago and its Health Service}

The Azores archipelago consists of nine islands distributed by three groups: Eastern Group (São Miguel and Santa Maria islands), Central Group (Terceira, São Jorge, Graciosa, Pico and Faial islands), and Western group (Flores and Corvo islands). According to the Serviço Regional de Estatístistica dos Açores (2020a), in 2019, the archipelago had a permanent population of 242796 individuals with significant asymmetry in its distribution by island. The islands of São Miguel, Terceira, and Faial concentrated 137856, 56437, and 14994 inhabitants, respectively, representing 86.2\% of the entire Azorean population. It is an aged region with a demographic ageing index of 97.2, a condition that places immense pressure on the health service. The average life 
expectancy at birth in the Azores has remained stable since 2003, fixing in 77.9 years in 2017, according to PORDATA data (2020).

According to data available from the Serviço Regional de Estatístistica dos Açores (2020c), the region verified a considerable increase in its floating population through the growth of tourism demand. In 2019, the Azores registered the entry of around 971794 non-residents, 512822 of which foreigners, a condition that requires the archipelago health service to strengthen its ability to respond against the increase in demand that derives from the growth in this non-resident population.

Under its statute, and concerning the health sector, the Azores Autonomous Region (Portugal) is competent in matters of health policy, namely its Regional Health Service (RHS), including its organisation, planning, functioning, financing, and human resources (PoliticalAdministrative Statute of the Azores Autonomous Region, 2009). Therefore, the Azores RHS guarantees the population's access, in conditions of universality, to quality health care by careful management of available resources, oriented towards the needs of its users, as a public task of great complexity. In the performance of such a task, it is essential to use the instruments and mechanisms, such as organisational and institutional nature, that allow the best results to be obtained. Thus, the healthcare professionals, including nurses, are part of it. The most valuable resource is the fulfilment of the mission and objectives of this health service (Statute of the Azores Regional Health Service, 2007).

Regarding the health resources available in the region, it should be noted that it has only three hospitals, which are distributed by the three most populous islands (São Miguel, Terceira and Faial). These three health institutions total 709 hospitalization beds (Serviço Regional de Estatístistica dos Açores, 2020b). Concerning human resources, in 2019, the Azores had a ratio of 3.6 physicians/1000 inhabitants and 8.8 nurses per 1000/inhabitants (Ordem dos Enfermeiros, 2020; Instituto Nacional de Estatística, 2021).

\section{Nursing Workforce and the $\mathbf{2 0 0 8}$ Financial Crisis Impact}

The need for a steady supply and maintenance of health personnel is a significant issue worldwide. In particular, the nursing workforce, which accounts for a large proportion of the health care workforce, should be welltrained, sufficiently available, adequately distributed by region, and efficiently utilised (OECD, 2017). A lower ratio of nursing staff to patients has been associated with increased mortality rates (Needleman et al., 2011). In addition, the incidence of complications, such as postoperative complications, and the length of hospital stay also tend to increase in the absence of adequate nursing to patient ratios. Considering the systematic review findings, assigning additional patients to each nurse increases deaths, resuscitations, and days 
spent in the hospital. Studies also have consistently reported that not only quantitative factors like the number of nurses but also qualitative factors, such as the proper placement of nursing staff, improved job satisfaction, the education level of nurses, and career length of nursing, affect patient's health outcomes (Aiken et al., 2010).

Despite nurses' importance in health systems, as shown above, the 2008 economic crisis heavily impacted on European nursing workforce. In some countries, the lack of nurses was amplified, thus creating, in others, working conditions that are not attractive for newly graduates. Consequently, both resulted in workforce shortages or with nurses leaving their clinical jobs (Rafferty et al., 2019).

\section{Nursing Shortage}

Health services rely on the availability of suitable qualified and experienced professionals to meet the health care expectations of the broader community. A fit for purpose health workforce is shaped by the supply of newly graduated professionals, the recruitment of experienced practitioners, and the country's economic health as the foundation for employment capacity (Gilmour et al., 2017; Cabrera, 2020).

Nursing workforce planning is complex due to patient's acuity and complexity, the nature of nursing activities, and staff turnover. These factors come together to raise the difficulty of planning the number of nurses needed to suppress the needs in health care beyond what is immediate. It aimed at the growing complexity of health systems through the changes made at the level of care systems, the ageing of the population and the increase in comorbidities associated with ageing, which will be felt over the next few decades (WellerNewton et al., 2021).

Globally, nursing is challenged with a predicted shortfall in the coming decades (Auerbach et al., 2017). This is with consequent workforce training challenges, compounded by skill mix, and all issues related to patient complexity and organisational unit instability (Duffield et al., 2018). No country is prepared for this predicted shortfall because health care organisations tend to focus reactively on the quick fix solution without realising the longer-term outcomes (Britnell, 2019).

\section{Youth Unemployment and New Graduates Difficulties}

The last financial and economic crisis, as earlier stated, aggravated macroeconomic distortions such as unemployment, especially for the young and the long-term type, increasing social and income disparities, and the distribution of income (Parisi, 2017). This is even more worrisome for countries like Portugal, Ireland, Greece, and Spain who have both limited financial and demographic resources to address future economic and social 
challenges and prevent further deterioration (Cvecic \& Sokolic, 2018). This juncture influenced young people and their position in the labour market, as many have been trying to find a job but are now threatened by the risk of prolonged joblessness and exclusion (Gontkovicocá et al., 2015; Calvo et al., 2018). Nurses and new nursing graduates are no exception to this situation, despite their critical role in health systems, particularly in countries experiencing more significant difficulties (Gilmour et al., 2017).

The transition from learning to working is one of the most important subjects connected with youth issues, as this is one of the most critical steps for integration in the community (Spatarelu, 2015). During the transition from student to nurse, newly graduated nurses grow and develop as professionals. Thus, this makes the transition a critical period in their new careers (Pfaff $e t$ al., 2014). Adverse experiences during the transitional period and in a situation of great instability and turnover, such as theory-practice, not feeling valued or respected, senior staff bullying or violent behaviours, unemployment or difficulties, and high precariousness in accessing the labour market are commonly reported reasons for new graduate nurses leaving nursing jobs (Edwards et al., 2015; Gardiner \& Sheen, 2016; Sondos, 2019).

Professional confidence and self-efficacy are vital components in the transition process because job stability and working conditions also play a decisive role in this process (Phillips et al., 2015). The first few years of nursing practice are critical because, during this period, new graduate nurses are filled with hopes and dreams and are most open to learning, they are excited, and their expectations are high (Ortiz, 2018). However, their expectations are often not met, and the difficulties they experience cause them to face a reality shock (Yildiz \& Ergun, 2020). The experiences gained by these nurses during this period will affect their commitment to the institutions and the profession, careers planning, and intentions of whether to leave or remain in the profession (Numminen et al., 2015).

\section{The Study}

Aims

The aim of this study is to determine the unemployment rate among Azorean nurses who graduated between 2008 and 2018, their current employment contract, and their first job characteristics. It also aimed to determine the possible impact the Portuguese Economic and Financial Assistance Program (2011-2014) had on Azorean nurse's employability dynamics in terms of the unemployment rate, type of contract and employer sector, and comparing it with the period immediately before (2008-2010) and after (2015-2018). It also tried to gather elements related to a possible intention to abandon the nursing practice and a possible relation with the mentioned program. 


\section{Method}

This quantitative study used descriptive, inferential, and correlational statistics to establish relations with a statistical value between the sample's employability characteristics/dimensions and the periods considered in the study, which correspond to before, during, and after the Portuguese Economic and Financial Assistance Program.

\section{Hypotheses}

Hypotheses construction for the current study was literature-based and are presented as follows:

Hypothesis 1: Unemployment rate does not relate to the period in which the participants finished their nursing degree.

Hypothesis 2: The participants' mean number of employment contracts do not relate to the period in which they finished their nursing degree.

Hypothesis 3: Mean wait (months), after finishing the nursing degree, until obtaining the first job does not relate to when the participants completed their nursing degree.

Hypothesis 4: First job employment contract type (temporary vs permanent) does not relate to the participants' period of finishing their nursing degree.

Hypothesis 5: The first job not corresponding to nursing practice did not relate to when the participants finished their nursing degrees.

Hypothesis 6: Employer's sector of activity regarding the first employment contract is not related to the period in which the participants finished their nursing degree.

Hypothesis 7: Intention to abandon nursing practice does not relate to when the participants finished their nursing degrees.

\section{Ethical Considerations}

Ethical approval was obtained from the Secção Regional da Região Autónoma dos Açores da Ordem dos Enfermeiros Regional Jurisdictional Council.

\section{Population and Sampling}

The study was conducted exclusively in Azores Autonomous Region, focusing on a population of nurses who graduated between 2008 and 2018, totalling 733 potential participants. The researcher electronically sent the invitation to the 733 subjects who constituted the access population through a questionnaire uploaded on the SurveyMonkey platform. Of the 733 invitations sent to participate, there were 24 "opt-outs" and a total of 580 valid responses, resulting in a participation rate of $79.1 \%$. 


\section{Instrument}

The instrument developed to collect data for this study was organised into four distinct sections: (1) demographic and nursing degree completionrelated questions, (2) current employment situation, (3) first job, and (4) intention to abandon nursing practice.

\section{Demographic and Nursing Degree Completion-Related Information}

This section of the questionnaire included the collection of information regarding gender, age, emplyees caring for the participant, island of residence, as well as issues related to nursing degree conclusion (year of completion, attending nursing degree course at the University of Azores, choice of this course as the first option, and participation in an international exchange program).

\section{Current Employment Situation Information}

Participants were asked whether they currently had a job, and the type of employment contract (permanent vs. temporary) concerning the current employment situation. If they were unemployed, they were asked whether they had ever worked in the past (in nursing or another area). Furthermore, they are asked about their current employer's sector of activity and salary grade.

\section{First Job Information}

Regarding their first job experience, the questionnaire aimed at collecting information related to whether this first job corresponded, or not, to nursing practice, employment contract type (permanent vs. temporary), employer's sector of activity, and salary grade.

\section{Intention to Abandon Nursing Practice}

The questionnaire last section addressed the intention to abandon the professional nursing practice, trying to understand whether this scenario was considered, or not, by the participant. If so, the reasons of the participant's opinion were at the origin of it.

\section{Data Collection}

Prior to the questionnaire implementation, the instrument was tested on a sample of 30 individuals with similar characteristics to those in the final sample. This procedure allowed the researcher to reformulate some questions and structure the questionnaire as efficiently as possible. The average duration for completing the questionnaire was 15 minutes. Each questionnaire had a checkbox for granting the respective free and informed consent to participate in the study. Data collection took place between May 1st and May 31st, 2019. The initial invitation was reinforced at the end of the second week of the 
questionnaire's application for non-respondents and the beginning of the last week's application.

\section{Data Analysis}

Statistical Package for the Social Sciences 25.0 software for Windows was used to ensure a practical statistical analysis. After checking for outliers and missing data, the descriptive analysis was initiated using absolute and relative frequencies, central tendency and dispersion measures, and inferential statistics. The significance level for rejecting the null hypothesis was set at $\rho$ $\leq 0.05$. The Chi-square independence test, Fisher's test, and the One-Way ANOVA test were used. According to the central limit theorem, variable distribution normality was accepted, considering samples with a dimension greater than 30 . The homogeneity of variances was analysed using the Levene test.

\section{Results}

Results are presented, for purposes of better organisation and clarity, in five distinct sections: 1) sample characterisation, 2) employment status, 3) the first job after graduation, 4) profession abandonment intention, and 5) financial assistance program's impact on nurse employment dynamics.

\section{Sample Characterisation}

The final sample consisted of 580 nurses (Table 1). The average participant is a female nurse $(82.8 \%)$, approximately 30 years old. The youngest participant was 22 years old and the oldest 54 years old. Most participants in the study sample do not have dependents in their direct care (72.8\%) and live, mainly, on two islands: São Miguel (46.6\%) and Terceira (35\%). Most participants completed their degree in nursing in 2008 (13.3\%). However, the participants' distribution over the remaining years included in the study was relatively homogeneous. Regarding participants' distribution by the periods considered for nursing degree's completion concerning the Portuguese Economic and Financial Assistance Program, it was also very balanced, in which $36.2 \%$ completing the degree in nursing before the beginning of the Program, 30.7\% did it during the Program's implementation, and $33.1 \%$ after the end of the Assistance Program.

About $89.5 \%$ of the participants attended their nursing degree at Azores University, and only $17.4 \%$ of the graduates participated in an international mobility/exchange program. 
European Scientific Journal, ESJ ISSN: 1857-7881 (Print) e - ISSN 1857-7431 February 2022 Bridging Language, Medicine, and Law

Table 1 - Sample Characterisation

\begin{tabular}{|c|c|c|}
\hline & Total & $\%$ \\
\hline \multicolumn{3}{|l|}{ Gender } \\
\hline Female & 480 & 82.8 \\
\hline Male & 100 & 17.2 \\
\hline Total & 580 & 100 \\
\hline \multicolumn{3}{|l|}{ Age group (years) } \\
\hline$<25$ & 61 & 10.5 \\
\hline$[25-30[$ & 203 & 35.0 \\
\hline$[30-35[$ & 259 & 44.7 \\
\hline$[35-40[$ & 41 & 7.1 \\
\hline$[40-45[$ & 10 & 1.7 \\
\hline$\geq 45$ & 6 & 1.0 \\
\hline$\overline{\text { Total }}$ & 580 & 100 \\
\hline \multicolumn{3}{|l|}{ Dependents on care } \\
\hline No & 422 & 72.8 \\
\hline Yes & 158 & 27.2 \\
\hline Total & 580 & 100 \\
\hline \multicolumn{3}{|l|}{ Island of residence } \\
\hline Flores island & 7 & 1.2 \\
\hline Santa Maria island & 10 & 1.7 \\
\hline São Jorge island & 15 & 2.6 \\
\hline São Miguel island & 270 & 46.6 \\
\hline Faial island & 44 & 7.6 \\
\hline Pico island & 22 & 3.8 \\
\hline Graciosa island & 9 & 1.6 \\
\hline Terceira island & 203 & 35.0 \\
\hline Total island & 580 & 100 \\
\hline \multicolumn{3}{|l|}{ Nursing degree completion (by year) } \\
\hline 2008 & 77 & 13.3 \\
\hline 2009 & 76 & 13.1 \\
\hline 2010 & 57 & 9.8 \\
\hline 2011 & 47 & 8.1 \\
\hline 2012 & 39 & 6.7 \\
\hline 2013 & 42 & 7.2 \\
\hline 2014 & 50 & 8.6 \\
\hline 2015 & 53 & 9.1 \\
\hline 2016 & 53 & 9.1 \\
\hline 2017 & 42 & 7.2 \\
\hline 2018 & 44 & 7.6 \\
\hline Total & 580 & 100 \\
\hline \multicolumn{3}{|c|}{$\begin{array}{l}\text { Nursing degree completion period (in reference to financial } \\
\text { assistance program) }\end{array}$} \\
\hline Before the financial assistance program (2008-2010) & 210 & 36.2 \\
\hline During the financial assistance program $(2011-2014)$ & 178 & 30.7 \\
\hline After the financial assistance program (2015-2019) & 192 & 33.1 \\
\hline Total & 580 & 100 \\
\hline \multicolumn{3}{|c|}{ Attendance to the nursing degree at the University of Azores } \\
\hline No & 61 & 10.5 \\
\hline Yes & 519 & 89.5 \\
\hline
\end{tabular}


European Scientific Journal, ESJ ISSN: 1857-7881 (Print) e - ISSN 1857-7431 February 2022

Bridging Language, Medicine, and Law

\begin{tabular}{lll} 
Total & 580 & 100 \\
Nursing degree as the first option & & \\
No & 67 & 11.6 \\
Yes & 513 & 88.4 \\
Total & 580 & 100 \\
Participation in an international mobility/exchange program & & \\
No & 479 & 82.6 \\
Yes & 101 & 17.4 \\
Total & 580 & 100 \\
\hline
\end{tabular}

\section{Employment Status}

As observed in Table 2, from the analysis of data on participants' current working situation, it is known that $2.8 \%$ are unemployed, $1.6 \%$, despite currently being unemployed, already had some kind of paid professional activity in the past, $1 \%$ despite having already worked never practised nursing, and finally, $0.2 \%$ of the participants never had a job.

Regarding participants who are currently employed, the vast majority have a permanent employment contract (85.6\%), with the public health sector being the leading employer $(74 \%)$, followed by the social economy sector (20\%), and finally, with little expression, the private health sector $(6 \%)$. Regarding remuneration, $61.7 \%$ of the participants are positioned in the level corresponding to the salary range between $€ 1000.00$ and $€ 1250.00$ (net amounts).

Table 2 - Sample Current Employment Situation Characterisation

\begin{tabular}{lll}
\hline & Total & $\%$ \\
\hline Current employment situation & 16 & 2.8 \\
Unemployed & 564 & 97.2 \\
Employed & 580 & 100 \\
Total & & \\
Current employment situation (detail) & 9 & 1.6 \\
Currently unemployed & 564 & 97.2 \\
Currently employed & 1 & 0.2 \\
Never been employed & 6 & 1.0 \\
Never employed as a nurse, but had another job & 580 & 100 \\
Total & & \\
Contract type & 483 & 85.6 \\
Permanent & 81 & 14.4 \\
Temporary & 564 & 100 \\
Total & & \\
Employer sector & 113 & 20.0 \\
Social economy sector & 34 & 6.0 \\
Private sector & 417 & 74.0 \\
Public sector & 564 & 100 \\
Total & & \\
Pay grade (euros - after taxation) & 2 & 0.4 \\
< 500 & 28 & 5.0 \\
[500-750[ & & \\
& &
\end{tabular}


European Scientific Journal, ESJ ISSN: 1857-7881 (Print) e - ISSN 1857-7431 February 2022 Bridging Language, Medicine, and Law

\begin{tabular}{lll}
{$[750-1000[$} & 96 & 17.0 \\
{$[1000-1250[$} & 348 & 61.7 \\
{$[1250-1500[$} & 77 & 13.7 \\
{$[[1500-1750[$} & 7 & 1.2 \\
{$[1750-2000[$} & 3 & 0.5 \\
$\geq 2000$ & 3 & 0.5 \\
Total & 564 & 100 \\
\hline
\end{tabular}

\section{First Job after Graduation}

Regarding the first job after the nursing degree end (see Table 3), this corresponded to nursing practice in $92.1 \%$ of cases. Concerning first job employment contract type (temporary $v s$. permanent), it was found that the vast majority of the employment contracts signed were precarious. Therefore, the job is temporary and totalling $83.9 \%$. Contrary to what was seen for current employment contracts, in the case of the first job, the social economy sector was the one that hired the most $(41.8 \%)$, followed by the public health sector $(40.2 \%)$, and finally, the private health sector (18\%). Thus, it has a higher expression than was verified in the current employment contracts.

From the available information, it was also found that the salary range practised (net values) for nursing graduates' first job was substantially lower than the ones practised in employment contracts currently held, with $40.5 \%$ of participants positioned in a salary range between $€ 500.00$ and $€ 750.00$, followed by the salary range between $€ 750.00$ and $€ 1000.00$ (31.6\%). The salary range between $€ 1000.00$ and $€ 1250.00$, which was more expressive for current employment contracts, represents, in this particular case (first job), only $16.9 \%$.

Table 3 - Sample First Job Position Characterisation

\begin{tabular}{lll}
\hline & Total & $\%$ \\
\hline First job corresponded to nursing practice & & \\
No & 46 & 7.9 \\
Yes & 533 & 92.1 \\
Total & 579 & 100 \\
Contract type & 93 & 16.1 \\
Permanent & 486 & 83.9 \\
Temporary & 579 & 100 \\
Total & & \\
Employer sector & 242 & 41.8 \\
Social economy sector & 104 & 18.0 \\
Private sector & 233 & 40.2 \\
Public sector & 579 & 100 \\
Total & & \\
Pay grade (euro's - after taxation) & 11 & 1.9 \\
< 500 & 262 & 45.3 \\
[500-750[ & 183 & 31.6 \\
[750-1000[ & 98 & 16.9 \\
[1000-1250[ & &
\end{tabular}


European Scientific Journal, ESJ ISSN: 1857-7881 (Print) e - ISSN 1857-7431 February 2022

Bridging Language, Medicine, and Law

\begin{tabular}{lll}
{$[1250-1500[$} & 21 & 3.6 \\
{$[1500-1750[$} & 4 & 0.7 \\
Total & 579 & 100 \\
\hline
\end{tabular}

\section{Profession Abandonment Intention}

Nursing practice abandonment intention was also addressed in this study, and it was found that $16.7 \%$ of the study participants (97 nurses) considered the possibility of leaving nursing to dedicate themselves to another professional activity. This can be seen in Table 4 analysis. In almost 30\% of cases, the origin of this hypothesis lies in the disappointment/disillusionment with nursing practice, followed by the feeling of professional non-fulfilment and the impossibility of foreseeing a future for nursing practice in Azores/Portugal. Issues related to job stability and the profession economic value (salary) are the minor valued factors for an eventual abandonment of the nursing practice.

Table 4 - Sample Intention to Abandon Nursing Practice

\begin{tabular}{lll}
\hline & Total & $\%$ \\
\hline Intention to abandon nursing practice & & \\
No & 483 & 83.3 \\
Yes & 97 & 16.7 \\
Total & 580 & 100 \\
Reason for the intention to abandon nursing practice & & \\
Nurse salary insufficient to daily responsibilities & 14 & 14.4 \\
Cannot get a permanent nursing position & 10 & 10.3 \\
Disappointment with nursing practice & 29 & 29.9 \\
Not fulfilled with nursing practice & 25 & 25.8 \\
Sees no future in nursing practice & 19 & 19.6 \\
Total & 97 & 100 \\
\hline
\end{tabular}

Financial Assistance Program Impact on Nurse Employment Dynamics

Hypotheses 1, 4, 5, and 6 were tested using the Chi-Square test (see Table 5). These hypotheses intended to determine statistically significant differences in employability status, type of contract, nursing practice in the first job held, and nursing practice abandonment intention through the threetime periods considered in the study (given the Economic and Financial Assistance Program). No statistically significant differences were found in hypotheses 1,5 , and 6 (employability status, first job corresponding to the nursing practice, and nursing practice abandonment intention); therefore, the null hypothesis was not rejected. However, for hypothesis 4 , the test result showed a significantly higher proportion of nurses with a permanent employment contract in the period preceding the Economic and Financial Assistance Program. In contrast, there are a considerably higher proportion of nurses with a temporary employment contract during the Post-Economic and Financial Assistance Program period. 
Table 5 - Chi-Square Test Results for Hypotheses 1, 4, 5 and 7

\begin{tabular}{|c|c|c|c|c|c|c|}
\hline \multirow{5}{*}{$\begin{array}{l}\text { Period (Portuguese Economic and } \\
\text { Financial Assistance Program) } \\
\text { Before } \\
\text { During } \\
\text { After }\end{array}$} & \multicolumn{2}{|c|}{ Employment status (\%) } & \multirow{2}{*}{ Value } & \multirow{2}{*}{$d f$} & \multirow{2}{*}{$\rho$} & \multirow{2}{*}{ Decision } \\
\hline & Unemployed & Employed & & & & \\
\hline & 1.4 & 98.6 & \multirow{3}{*}{4.221} & \multirow{3}{*}{2} & \multirow{3}{*}{0.121} & \multirow{3}{*}{$\begin{array}{l}\text { Not reject } \\
\mathrm{H}_{0}\end{array}$} \\
\hline & 2.2 & 97.8 & & & & \\
\hline & 4.7 & 95.3 & & & & \\
\hline \multicolumn{7}{|l|}{ Hypothesis 4} \\
\hline Period (Portuguese Economic and & \multicolumn{2}{|c|}{ Contract type (\%) } & & & & Decicion \\
\hline Financial Assistance Program) & Permanent & Temporary & Value & df. & $\rho$ & Decision \\
\hline Before & 97.1 & 2.9 & & & & \\
\hline During & 87.4 & 12.6 & 54.250 & 2 & $0.001 *$ & Reject $\mathrm{H}_{0}$ \\
\hline After & 71.0 & 29.0 & & & & \\
\hline \multicolumn{7}{|l|}{ Hypothesis 5} \\
\hline Period (Portuguese Economic and & \multicolumn{2}{|l|}{ First job (\%) } & Value & & & Decicion \\
\hline Financial Assistance Program) & Non-nursing & Nursing & Value & df. & $\rho$ & Decision \\
\hline Before & 5.7 & 94.3 & & & & Not reject \\
\hline During & 11.2 & 88.8 & 4.164 & 2 & 0.125 & Not reject \\
\hline After & 7.3 & 92.7 & & & & \\
\hline \multicolumn{7}{|l|}{ Hypothesis 7} \\
\hline Period (Portuguese Economic and & \multicolumn{2}{|c|}{ Nursing abandonment (\%) } & Volue & $d f$ & & Decicion \\
\hline Financial Assistance Program) & No & Yes & Value & $d f$. & $\rho$ & Decision \\
\hline Before & 81.9 & 18.1 & & & & \\
\hline During & 82.6 & 17.4 & 0.976 & 2 & 0.614 & Not reject \\
\hline After & 85.4 & 14.6 & & & & \\
\hline
\end{tabular}

$\mathrm{H}_{0}$, null hypotheses

*Significant if $\rho<0,05$

Hypothesis 6 was also tested using the Chi-Square test to assess the existence of statistically significant differences between the sectors that, in the Azores, typically hire nurses, considering their first job, in each of the three periods under study (see Table 6). The test result concluded that there was a statistically significant difference between the first employer's sector and the time segments understudy. For this reason, the null hypothesis was rejected. During the period in which the Economic and Financial Assistance Program ran, the social economy sector was the one that hired the most nurses (54.5\%), contrary to what happened in the periods before and after the program, while the public sector was the largest employer, hiring practically $50 \%$ of all available nurses. 
European Scientific Journal, ESJ ISSN: 1857-7881 (Print) e - ISSN 1857-7431 February 2022

Bridging Language, Medicine, and Law

Table 6 - Chi-Square Test Results for Hypothesis 6

\begin{tabular}{lllllllll}
\hline \multicolumn{2}{c}{ Hypothesis 6} \\
\hline Period (Portuguese & \multicolumn{1}{c}{ First job sector (\%) } & & & & & & \\
Economic and Financial & Social & Private & Public & Value & $d f$. & $\rho$ & & Decision \\
Assistance Program) & economy & & & & & \\
Before & 34.3 & 18.6 & 47.1 & & & & \\
During & 54.5 & 21.3 & 24.2 & 29.551 & 4 & $0.000 *$ & Reject $\mathrm{H}_{0}$ \\
After & 38.2 & 14.1 & 47.6 & & & & \\
\hline $\mathrm{H}_{0}$, null hypotheses & & & & & & & \\
$*$ Significant if $\rho<0,05$ & & & & & & & & \\
\hline
\end{tabular}

The Portuguese Economic and Financial Assistance Program impact on participants' mean number of employment contracts and the mean waiting (in months) after finishing nursing degree until getting the first job was tested using a one-way ANOVA test (hypothesis 2 and 3) as seen in Table 7.

There are statistically significant differences between the period when nursing graduation took place and the number of employment contracts the participants held, thus, rejecting the null hypothesis. The number of different employment contracts held by the participants is higher for nurses who completed their nursing degree during the period in which the Economic and Financial Assistance Program took place. Also, it was lower for nurses who completed their degree after the end of the program's implementation period and the period before it.

Concerning the average wait (in months) until obtaining the first employment contract after completing the nursing degree, there were statistically significant differences between periods; therefore, the null hypothesis was rejected. In the period comprising the Economic and Financial Assistance Program implementation, the average wait until the signing for the first employment contract was significantly higher (6.37 months) when compared with the previous period (5.09 months) and with the subsequent period (1.85 months). 
European Scientific Journal, ESJ ISSN: 1857-7881 (Print) e - ISSN 1857-7431 February 2022

Bridging Language, Medicine, and Law

Table 7 - One-way ANOVA Test Results for Hypotheses 2 and 3

\begin{tabular}{|c|c|c|c|c|c|c|}
\hline $\begin{array}{l}\text { Period (Portuguese Economic and } \\
\text { Financial Assistance Program) }\end{array}$ & $\begin{array}{l}\text { No. e } \\
\text { contracts } \\
\text { Mean (m) }\end{array}$ & $\begin{array}{l}\text { mployment } \\
\text { SD }\end{array}$ & $\mathrm{F}$ & $d f$ & $\rho$ & Decision \\
\hline Before & 2.23 & 1.051 & & & & \\
\hline During & 2.56 & 1.306 & 17.136 & 2 & $0.000 *$ & Reject $\mathrm{H}_{0}$ \\
\hline After & 1.85 & 1.026 & & & & \\
\hline \multicolumn{7}{|l|}{ Hypothesis 3} \\
\hline \multirow{2}{*}{$\begin{array}{l}\text { Period (Portuguese Economic and } \\
\text { Financial Assistance Program) }\end{array}$} & \multicolumn{2}{|c|}{$\begin{array}{l}\text { Wait (months) until } \\
\text { first job }\end{array}$} & $\mathrm{F}$ & $d f$ & $\rho$ & Decision \\
\hline & Mean (m) & SD & & & & \\
\hline Before & 5.09 & 5.731 & & & & \\
\hline During & 6.37 & 8.329 & 4.884 & 2 & $0.008 *$ & Reject $\mathrm{H}_{0}$ \\
\hline After & 4.28 & 4.214 & & & & \\
\hline $\begin{array}{l}\mathrm{H}_{0}, \text { null hypotheses } \\
\mathrm{SD} \text {, Standard deviation } \\
* \text { Significant if } \rho<0,05\end{array}$ & & & & & & \\
\hline
\end{tabular}

From the results presented so far, it is possible to extract that some variables associated with employability and the labour market in the case of nurses were, in fact, negatively impacted as a result of the Portuguese Economic and Financial Assistance Program. These findings are discussed in greater depth in the next section of the manuscript.

\section{Discussion}

From the analysis carried out, the study found that the EconomicFinancial Adjustment Program directly impacted employment contracts made with nurses for their first job. In the pre-intervention period, permanent employment contracts predominated, with a decrease in their proportion during the adjustment period, a dangerous tendency that continued after the end of the program. This is with a very significant increase in unstable/temporary employment contracts.

The unemployment rate registered among the participants was low, around $2.8 \%$, which also, in this context, may indicate a high demand for these health care professionals as described in the literature (Anderson et al., 2021). This finding can point to the scarcity of these professionals and the permanent need for their recruitment to reinforce the health care teams (Park \& Yu, 2019). Although there were 16 unemployed participants, it is not possible to assume that this unemployment is due to local labour market saturation. This is so that, in future studies, it would be interesting to explore the reasons underlying the fact that unemployed nurses remain in this condition. Thus, it aims to determine whether they remain so due to lack of employment opportunities or 
any other reason. Only one participant reported never having had any job at the time of the questionnaire's application.

As it happens in other European countries and regions, the public sector is one of the major employers in the health sector (Melly \& Puhani, 2013; Clark \& Milcent, 2018). This preponderance of the public sector in the health area is more relevant as the way the health system is presented and organized in each country. In the case of Portugal, as in most of its European counterparts, health care is provided mainly by public services (Clark \& Milcent, 2011; Bloom et al., 2015), with universal access, and financed by contributions and taxes. Thus, it is not surprising that for $74 \%$ of the nurses who participated in the study, the public sector was the primary employer, followed by the social sector (20\%), and finally, the private sector $(6 \%)$. Additionally, despite a $14.4 \%$ rate of precarious employment contracts among the participants, the vast majority holds a permanent employment contract. Hence, this is a fundamental condition for nurses to plan a professional growth and development path (Kim \& Shin, 2020). The monthly remuneration category most represented in the study, for present contracts, stood between 1000.00 and 1250.00 Euro, which corresponds to the monthly remuneration established in Portugal for nurses at the beginning of their career in the public sector.

Regarding participants' first job, there is a situation quite different from the one verified in the employment contract held when the questionnaire was applied. To start with, around $7.9 \%$ of the participants assumed that their first job did not correspond to nursing practice (it is necessary to go deeper into this topic in future research to qualify this phenomenon as circumstantial or voluntary). In $83.9 \%$ of cases, the first employment contract was temporary, contrary to most employment contracts held at the time of questionnaire application, which was essentially permanent, a characteristic widely identified in the literature that focuses on the study of youth employment and precariousness (Marelli et al., 2013). Concerning first job employment contracts, the public sector was not the largest employer as they are second in ranking. In this case, the social economy sector assumes the top position, retaining $41.8 \%$ of the new nursing graduates. As for remuneration in their first employment contract, there are also considerable discrepancies compared with current employment contracts, as in this case, the most represented remuneration scale was situated between 500.00 and 750.00 Euros. Among the participants, about $16.7 \%$ of the samples (which correspond to 97 nurses) consider the possibility of abandoning the nursing practice. When asked about the underlying reasons for this, the three most frequent causes were: "disappointment with nursing practice" (29.9\%), "not fulfilled with nursing practice" (25.8\%), and "sees no future in nursing practice" (19.6\%). Although $10.3 \%$ of the participants consider abandoning nursing practice for not getting 
a permanent employment contract, this is not the most important reason. The predominant causes for abandonment intention are reasoned by aspects much more related to the nursing practice, the way participants felt about the profession and themselves as professionals (aspects widely discussed in the literature and known to play a determining role in the way new nursing graduates face the profession), and their ability to respond to the demands of professional exercise (Chang et al., 2018). An important part of this disenchantment may be rooted in the lack of recognition that nurses still suffer, with a substantial undervaluation of their professional and social value, a widely recognized reason for abandoning the profession, aggravated by poor working conditions (WHO, 2020; All-Party Parliamentary Group on Global Health, 2016).

During the Portuguese Economic and Financial Assistance Program (2011-2014) implementation, the public health service was no longer the largest nursing employer, falling from $47.1 \%$ to $24.2 \%$, recovering its top position regarding nursing hiring after the external assistance program's end. Based on this, it can be assumed that public health services may have been under tremendous pressure due to insufficient nurses and the impossibility of hiring new ones during the program's implementation. As restrictions on hiring new professionals were lifted, the public employer quickly regained first place among the sectors that traditionally employ most nurses.

The period during which the program took place was also the one with the most significant instability regarding employment contracts made with nurses, that is, between 2011 and 2014. The participants had, on average, 2.56 employment contracts, as opposed to 2.23 registered in the pre-intervention period and 1.85 reported in the post-programme period. Also, regarding the average wait in months until obtaining the first employment contract, there was a significant increase in this parameter during the program's implementation, going from 5.09 months to 6.37 months, and dropping to 4.28 after its conclusion.

Precariousness is one of the known effects of recessive cycles on employment dynamics, as it has already been identified by previous research studies in this field. In the aftermath of severe economic crises and the absence of solid public policies directed to youth employability and labour integration, aiming full professional development and integration, there is a high risk of condemning the younger generations to a cycle of precariousness, professional and social devaluation, and exclusion (Gontkovicocá et al., 2015; Calvo et al., 2018; Cvecic \& Sokolic, 2018). This will have a very significant and negative repercussions on society as a whole, thus, enhancing the cycle of poverty and asymmetries in income distribution (Livanos et al., 2012; Cvecic \& Sokolic, 2018). One of the possible alternatives is to resort to emigration to escape the cycle of precariousness and poverty imposed by unemployment, especially 
among the youngest. Although the phenomenon of emigration was not addressed in this study, the literature on the subject, specifically concerning Portugal, supports the possibility that in the Azores, the strong contraction observed in the public expenditure (given that public health services have been hit hard by budget restrictions) due to the imposed austerity measures, could also have generated an emigration wave of nurses. The period during which the adjustment program was in force plunged Portugal into austerity, without great expectations of job creation also in the health sector, leading to the departure abroad by newly graduated nurses who were looking for their first employment contract as majority left for the United Kingdom (Pereira et al., 2015; Pereira, 2019). There are no objective data on Azorean nurses who emigrated during the Portuguese Economic and Financial Assistance Program implementation. However, at a national level, it is known that the number of nurses to emigrate increased from about 500 per year in 2010 to more than 2000 per year between 2013 and 2014. This is considered a consequence of the austerity measures applied in Portugal and the contraction of public expenditure and the economy, which severely limited the absorption of these professionals by the national labour market (Pereira, 2019). There may have also been an intensification of the outflow of nurses abroad in the Azores on its scale.

\section{Conclusion}

The Portuguese Economic and Financial Assistance Program had considerable effects on the employability of Azorean nurses and the nursing labour market dynamics in the Azores. This situation was most likely felt with this intensity because public services, including health services, were subject to solid budgetary restrictions, namely stringent limits on personnel hiring.

This was the first study carried out in Portugal and in the Azores islands, whose main objective was to characterize the employability of nurses in such an extended period. Additionally, it was also the first study to assess the Portuguese Economic and Financial Assistance Program's possible impact on this group of health care professionals, namely nursing hiring, and the conditions in which the hiring was carried out.

In summary, this study made clear that the Portuguese Economic and Financial Assistance Program worsened the precariousness of nurses' employment contracts in the Azores, both during its implementation and in subsequent years. Likewise, despite being undercapitalized in the number of nurses, the public health sector drastically reduced the hiring of nurses during the adjustment period, moving to second place among the sectors that hire nurses the most. It was also found that, during the Program implementation, nurses were subject to greater labour instability, with an average number of employment contracts per nurse considerably higher than that recorded in the 
period before and after Program implementation. Finally, during the Program, the average waiting (months) until obtaining the first employment contract (regardless of the type) was significantly higher than the remaining periods considered in the study.

\section{Limitations and Future Research}

With the emergence of the COVID-19 pandemic in early 2020, it would be very interesting to replicate this study to understand its impact on the dynamics of professional insertion and employability of Azorean nurses, particularly among newly graduated nurses. It would also be important to understand, in response to the pandemic, whether the proportion of nurses who consider leaving the profession has increased, as, during this period, the health care services and its professionals were under unprecedented pressure and stress, carrying out their professional activity under very challenging conditions and, in some cases, without minimum requirements.

This study focused only on a population subgroup in the Universe of Azorean nurses, intending to analyse the employability and dynamics of the labour market of new graduate nurses in the Azores Autonomous Region following the financial crisis of 2009-2010. However, it did not address some important aspects, such as those related to female discrimination in relation to salary or employment stability (considering a professional group mainly composed of women), and the study of the dynamics of the labour market in other subgroups of the Azorean nurse population, such as nurses with more years of professional exercise (to perceive whether the external intervention to which Portugal was submitted also negatively impacted them). In addition to the topics indicated for future investigation already in the first paragraph, these additional research lines are also noted because in the event followed, they can better characterize the nurses' labour market in the Azores, as well as their employability in a broader and more comprehensive manner, thus, understanding more profoundly this reality.

As limitations to the study, it is identified, firstly, the fact that data on unemployment reflected the reality when the questionnaire was applied (May 2019). Regardless of this fact, which does not show the current unemployment rate among Azorean nurses, the importance of this information must be emphasized. No study on this topic was carried out in the Azores Autonomous Region or Portugal. Thus, it brings to the light of science relevant information that can be compared with the results of future similar studies that could be carried out.

Another limitation is that the study did not explore the reasons underlying the unemployment rate found among the participants (although residual). This information is particularly necessary to understand the phenomenon of unemployment in this professional group, to untangle whether 
it results from unfavourable conditions of the nurses' labour market, which do not generate enough positions for the available graduates. If it is voluntary unemployment, if verified, it should be a circumstance that should merit due analysis.

\section{References:}

1. Aiken, L. H., Sloane, D. M., Cimiotti, J. P., Clarke, S. P., Flynn, L., Seago, J. A., Spetz, J. \& Smith, H. L. (2010). Implications of the California nurse staffing mandate for other states. Health Services Research. 45(4), 904-921. https://doi.org/10.1111/j.14756773.2010.01114.x.

2. Al-Sawai'e, K. M., \& Abdul A'aL, S. (2015). The impact of trade account deficit on unemployment scenario: An empirical study on Jordan during the period of 2000-2012. European Scientific Journal. 11(16),

318-333. https://eujournal.org/index.php/esj/article/view/5871.

3. All-Party Parliament Group on Global Health (2016). Triple Impact How developing nursing will improve health, promote gender equality and support economic growth. Key Points and Recommendations. House of Commons, London.

4. Anderson, M., O'Neill, C., Clark, J. M., Street, A., Woods, M., Johnston-Webber, C., Charlesworth, A., Whyte, M., Foster, M., Majeed, A., Pitchforth, E., Mossialos, E., Asaria, M. \& McGuire, A. (2021). Securing a sustainable and fit-for-purpose UK health and care workforce. The Lancet. 397(10288), 1992 - 2011. https://doi.org/10.1016/S0140-6736(21)00231-2.

5. Arulampalam, W., Booth, A. L. \& Taylor, M. P. (2000). Unemployment persistence. Oxford Economic Papers. 52(1), 24-50. https://doi.org/10.1093/oep/52.1.24.

6. Auerbach, D. I., Buerhaus, P. I. \& Staiger, D. O. (2017). How fast will the registered nurse workforce grow through 2030? Projections in nine regions of the country. Nursing Outlook. 65(1), 116-122. https://doi.org/10.1016/j.outlook.2016.07.004.

7. Banco de Portugal (July 30, 2021) - Programa de Assistência Económica e Financeira. Banco de Portugal, 2015. https://www.bportugal.pt/page/programa-de-assistencia-economica-efinanceira.

8. Benach, J., Vives, A., Amable, M., Vanroelen, C., Tarafa G. \& Muntaner C. (2014). Precarious employment: understanding an emerging social determinant of health. Annual Review of Public Health. 35, 229-253. https://doi.org/10.1146/annurev-publhealth032013-182500. 
9. Bloom, N., Propper, C., Seiler, S. \& Van Reenen, J. (2015). The Impact of Competition on Management Quality: Evidence from Public Hospitals. The Review of Economic Studies. 82(2), 457-489. https://doi.org/10.1093/restud/rdu045.

10. Boeri, T. \& Jimeno, J. F. (2016). Learning from the Great Divergence in Unemployment in Europe during the Crisis. Labour Economics. 41(C), 32-46. https://doi.org/10.1016/j.labeco.2016.05.022

11. Britnell, M. (2019). Human: Solving the global workforce crisis in healthcare. Oxford University Press, Oxford.

12. Cabrera, E. (2020). Nurses workforce and competencies. A challenge for health systems more than ever. Nurse Education in Practice. 48,102858. https://doi.org/10.1016/j.nepr.2020.102858

13. Calvo, F., Carbonell, X. \& Badia, M. (2018). Homelessness and Unemployment During the Economic Recession: The Case of the City of Girona. European Scientific Journal. 14(13), 59-74. https://doi.org/10.19044/esj.2018.v14n13p59

14. Chang, H. Y., Friesner, D., Chu, T. L., Huang, T. L., Liao, Y. N. \& Teng, C. I. (2018). The impact of burnout on self-efficacy, outcome expectations, career interest and nurse turnover. Journal of Advanced Nursing. 74(11), 2555-2565. https://doi.org/10.1111/jan.13776

15. Clark, A. E. \& Milcent, C. (2011). Public employment and political pressure: The case of French hospitals. Journal of Health Economics. 30(5), 1103-1112.

https://doi.org/10.1016/j.jhealeco.2011.07.007

16. Clark, A. E. \& Milcent, C. (2018). Ownership and hospital behaviour: Employment and local unemployment. Social Science \& Medicine. 202, 151-161. https://doi.org/10.1016/j.socscimed.2018.02.027

17. Cvecic, I. \& Sokolic, D. (2018). Impact of public expenditure in labour market policies and other selected factors on youth unemployment. Economic Research-Ekonomska Istraživanja. 31(1), 2060-2080. https://doi.orr/10.1080/1331677X.2018.1480970

18. Diário da República Eletrónico (July 30, 2021) - Estatuto do Serviço Regional de Saúde dos Açores, 2007 [Statute of the Azores Regional Service] - Decreto Legislativo Regional n. ${ }^{\circ}$ 2/2007/A, de 24 de janeiro de 2007. https://dre.pt/web/guest/pesquisa/-/search/522648/details/normal?l=1

19. Diário da República Eletrónico (July 30,2021) - Estatuto PolíticoAdministrativo da Região Autónoma dos Açores, 2009 [PoliticalAdministrative Status of the Autonomous Region of the Azores] - Lei n. ${ }^{\circ}$ 2/2009, de 12 de janeiro de 2009. https://dre.pt/home//dre/397322/details/maximized 
20. Duffield, C., Roche, M. A., Twigg, D., Williams, A., Rowbotham, S. \& Clarke, S. (2018). Adding unregulated nursing support workers to ward staffing: Exploration of a natural experiment. Journal of Clinical Nursing. 27(19-20), 3768-3779. http://dx.doi.org/10.1111/jocn.14632

21. Edwards, D., Hawker, C., Carrier, J., \& Rees, C. (2015). A systematic review of the effectiveness of strategies and interventions to improve the transition from student to newly qualified nurse. International Journal of Nursing Studies. 52(7), 1254-1268. https://doi.org/10.1016/j.ijnurstu.2015.03.007

22. Faramarzi, A., Javan-Noughabi, J., Sadeghi, A. \& Rezapour, A. (2019). Impact of the economic crisis on healthcare resources: A panel data analysis in Eastern Mediterranean countries during 2005 to 2013. Clinical Epidemiology and Global Health. 7(1), 98-101. https://doi.org/10.1016/j.cegh.2018.02.004

23. Frenk, F. (2010). The World Health Report 2000: Expanding the horizon of health system performance. Health Policy and Planning. 25(5), 343-345. https://doi.org/10.1093/heapol/czq034

24. Gardiner, I. \& Sheen, J. (2016). Graduate nurse experiences of support: A review. Nurse Education Today. 40, 7-12. https://doi.org/10.1016/j.nedt.2016.01.016

25. Gilmour, J., Huntington, A., Slark, J. \&Turner, C. (2017). Newly graduated nurses and employment: A dynamic landscape. Collegian. 24(3), 247-253. https://doi.org/10.1016/j.colegn.2016.02.004

26. Gontkovičová, B., Mihalčová, B. \& Pružinský, M. (2015). Youth Unemployment - Current Trend in the Labour Market? Procedia Economics and Finance. 23, 1680-1685. https://doi.org/10.1016/S2212-5671(15)00554-7

27. Park, H. \& Yu, S. (2019). Effective policies for eliminating nursing workforce shortages: A systematic review. Health Policy and Technology. 8(3), 296-303. https://doi.org/10.1016/j.hlpt.2019.08.003

28. INE (2021). Estatísticas da Saúde - 2019. Instituto Nacional de Estatística, Lisboa.

29. Karanikolos, M., Mladovsky, P., Cylus, J., Thomson, S., Basu, S., Stuckler, D., Mackenbach, J. P. \& McKee, M. (2013). Financial crisis, austerity, and health in Europe. The Lancet. 381(9874), 1323-1331. https://doi.org/10.1016/S0140-6736(13)60102-6

30. Keegan, C., Thomas, S., Normand, C. \& Portela, C. (2013). Measuring recession severity and its impact on healthcare expenditure. International Journal of Health Care Finance and Economics. 13(2), 139-155. https://doi.org/10.1007/s10754-012-9121-2 
31. Kentikelenis, A. E. (2017). Structural adjustment and health: A conceptual framework and evidence on pathways. Social Science \& Medicine. 187, 296-305.

https://doi.org/10.1016/j.socscimed.2017.02.021

32. Kentikelenis, A. \& Papanicolas, I. (2012). Economic crisis, austerity and the Greek public health system. European Journal of Public Health. 22(1), 4-5. https://doi.org/10.1093/eurpub/ckr190

33. Kim, J., H. \& Shin, H. S. (2020). Exploring barriers and facilitators for successful transition in new graduate nurses: A mixed methods study. Journal of Professional Nursing. 36(6), 560-568. https://doi.org/10.1016/j.profnurs.2020.08.006

34. Leão, T., Campos-Matos, I., Bambra, C., Russo, G. \& Perelman, J. (2018). Welfare states, the Great Recession and health: Trends in educational inequalities in self-reported health in 26 European countries. PLoS One. 13(2), e0193165. https://doi.org/10.1371/journal.pone.0193165

35. Liotti, G. (2020). Labour market flexibility, economic crisis and youth unemployment in Italy. Structural Change and Economic Dynamics. 54(C), 150-162. https://doi.org/10.1016/j.strueco.2020.04.011

36. Livanos, I., Ilaria Maselli, I., Imanol Núñez, I., Riddell, W. C., Scarpetta, S., Song, X., \& Sonnet A. (2012). Challenges Facing European Labour Markets: Is a Skill Upgrade the Appropriate Instrument? Intereconomics. 47(1), 4-30. https://doi.org/10.1007/s10272-012-0402-2

37. Marelli, E., Choudhry, M. \& Signorelli, M. (2013). Youth and total unemployment rate: The impact of policies and institutions. Rivista Internazionale Di Scienze Sociali. 121(1), 63-86. http://www.jstor.org/stable/26477700

38. Melly, B. \& Puhani, P. A. (2013). Do Public Ownership And Lack Of Competition Matter For Wages And Employment? Evidence From Personnel Records Of A Privatized Firm. Journal of the European Economic Association. 11(4). 918-944. https://doi.org/10.1111/jeea.12024

39. Needleman, J., Buerhaus, P., Pankratz, V. S., Leibson, C. L., Stevens, S. R. \& Harris, M. (2011). Nurse staffing and inpatient hospital mortality. New England Journal of Medicine. 364(11), 1037-1045. https://doi.org/10.1056/NEJMsa1001025

40. Numminen, O., Leino-Kilpi, H., Isoaho, H. \& Meretoja, R. (2015). Newly Graduated Nurses' Competence and Individual and Organizational Factors: A Multivariate Analysis. Journal of Nursing Scholarship. 47(5),446-457. https://doi.org/10.1111/jnu.12153 
41. OECD (2017). Health at a Glance 2017: OECD Indicators. OECD Publishing, Paris.

https://doi.org/10.1787/health_glance-2017-en

42. Ordem dos Enfermeiros (2020). Anuário Estatístico 2019. Ordem dos Enfermeiros, Lisboa.

43. Ortiz, J. (2016). New graduate nurses' experiences about lack of professional confidence. Nurse Education in Practice. 19, 19-24. https://doi.org/10.1016/j.nepr.2016.04.001

44. Parisi, M. L. (2017). Labor market rigidity, social policies and the labor share: Empirical evidence before and after the big crisis. Economic Systems. 41(4), 492-512. https://doi.org/10.1016/j.ecosys.2017.08.003

45. Pereira, C. (2019). A New Skilled Emigration Dynamic: Portuguese Nurses and Recruitment in the Southern European Periphery. In: Pereira, C. \& Azevedo, J. (eds). New and Old Routes of Portuguese Emigration. IMISCOE Research Series. Springer, Cham. https://doi.org/10.1007/978-3-030-15134-8_5

46. Pereira, C., Pinto, N. \& Pires, R. P. (2015). Portuguese nurses in the UK 2014. OEm Fact Sheets, 3. Observatório da Emigração, CIESIUL, ISCTE-IUL. 3, 1-15. http://hdl.handle.net/10071/8937

47. Pfaff, K., Baxter, P., Jack, S. \& Ploeg, J. (2014). An integrative review of the factors influencing new graduate nurse engagement in interprofessional collaboration. Journal of Advanced Nursing. 70(1), 4-20. https://doi.org/10.1111/jan.12195

48. Phillips, C., Esterman, A. \& Kenny, A. (2015). The theory of organisational socialisation and its potential for improving transition experiences for new graduate nurses. Nurse Education Today. 35(1), 118-124. https://doi.org/10.1016/j.nedt.2014.07.011

49. PORDATA (2020). Retrato dos Açores - Edição 2020. Fundação Francisco Manuel dos Santos, Lisboa.

50. Rafferty, A. M., Busse, R., Zander-Jentsch, B., Sermeus, W. \& Bruyneel, L. (2019). Strengthening health systems through nursing: Evidence from 14 European countries [Internet]. Copenhagen (Denmark): European Observatory on Health Systems and Policies; 2019. (Health Policy Series, No. 52.) Available from: https://www.ncbi.nlm.nih.gov/books/NBK545724/

51. Simou, E. \& Koutsogeorgou, E. (2014). Effects of the economic crisis on health and healthcare in Greece in the literature from 2009 to 2013: A systematic review. Health Policy. 115(2-3), 111-119. https://dx.doi.org/10.1016/j.healthpol.2014.02.002 
52. Sondos, J.A.A. (2019). The Benefits of Unemployment Insurance Fund in Jordan. European Scientific Journal. 15(4), 333-352. https://doi.org/10.19044/esj.2019.v15n4p333

53. Spatarelu, E. M. (2015). Youth Insertion on Labor Market. Procedia Economics and Finance. 32, 1020-1026. https://doi.org/10.1016/S2212-5671(15)01563-4

54. SREA (2020). Demografia 2019. Serviço Regional de Estatística dos Açores, Angra do Heroísmo.

55. SREA (2020). Estatísticas da Saúde. Serviço Regional de Estatística dos Açores, Angra do Heroísmo.

56. SREA (2020). Estatísticas do Turismo. Serviço Regional de Estatística dos Açores, Angra do Heroísmo.

57. Thomas, S., Keegan, C., Barry, S., Layte, R., Jowett, M. \& Normand, C. (2013). A framework for assessing health system resilience in an economic crisis: Ireland as a test case. BMC Health Services Research. 13(450), 1-8. http://doi.org/10.1186/1472-6963-13-450

58. Weller-Newton, J. M., Phillips, C., Roche, M. A., McGillion A., Mapes, P., Dufty, T., Schlieff, J., Boyd, L., Geary, A. \& Haines, S. (2021). Datasets to support workforce planning in nursing: A scoping review.

Collegian.

$28(3)$

324-332.

https://doi.org/10.1016/j.colegn.2020.09.001

59. WHO (2020). State of the world's nursing 2020: Investing in education, jobs and leadership. World Health Organization, Geneva.

60. Yildiz, C.C. \& Ergun, E. (2020). Transition Experiences of Newly Graduated Nurses. Clinical and Experimental Health Sciences, 10(2), 113-119. https://doi.org/10.33808/clinexphealthsci.604266 